\title{
Identification of the Tobacco Blue Mold Pathogen, Peronospora tabacina, by Polymerase Chain Reaction
}

Jean Beagle Ristaino, Andrea Johnson, Monica Blanco-Meneses, and Bo Liu, Department of Plant Pathology, North Carolina State University, Raleigh 27695

\begin{abstract}
Ristaino, J. B., Johnson, A., Blanco-Meneses, M., and Liu, B. 2007. Identification of the tobacco blue mold pathogen, Peronospora tabacina, by polymerase chain reaction. Plant Dis. 91:685691.

Tobacco blue mold, caused by the oomycete pathogen Peronospora tabacina, is a highly destructive pathogen of tobacco (Nicotiana tabacum) seed beds, transplants, and production fields in the United States. The pathogen also causes systemic infection in transplants. We used polymerase chain reaction (PCR) with the primers ITS4 and ITS5, sequencing, and restriction digestion to differentiate $P$. tabacina from other important tobacco pathogens, including Alternaria alternata, Cercospora nicotianae, Phytophthora glovera, P. parasitica, Pythium aphanidermatum, P. dissotocum, P. myriotylum, P. ultimum, Rhizoctonia solani, Sclerotinia sclerotiorum, Sclerotium rolfsii, Thielaviopsis basicola, and related Peronospora spp. A specific PCR primer, called PTAB, was developed and used with ITS4 to amplify a 764-bp region of DNA that was diagnostic for $P$. tabacina. The PTAB/ITS4 primers did not amplify host DNA or the other tobacco pathogens and were specific for $P$. tabacina on tobacco. DNA was detected to levels of $0.0125 \mathrm{ng}$. The PTAB primer was useful for detection of the pathogen in fresh, air-dried, and cured tobacco leaves. This primer will be useful for disease diagnosis, epidemiology, and regulatory work to reduce disease spread among fields.
\end{abstract}

Additional keyword: oomycetes

Blue mold is a devastating downy mildew disease of tobacco (Nicotiana tabacum) caused by the Oomycete pathogen Peronospora tabacina Adam (17,21,24,35). $P$. tabacina is an obligate parasite and cannot be cultured in vitro $(17,22,35)$. Sporangiospores of $P$. tabacina do not produce zoospores, and infection occurs via direct germination $(6,35)$. The asexual sporangiospores of the pathogen can be dispersed thousands of kilometers and are the primary source of inoculum for epidemics $(7-9,35)$. In the United States, sporangiospores may be spread yearly to commercial tobacco from wild tobacco in Texas or may originate in Caribbean countries and move northward and infect tobacco as it is planted in fields $(1,8,9,15,18,19,24,34)$. Tobacco blue mold is also a problem in southwestern and southeastern Europe, the Middle East, and North Africa. Inoculum may overwinter in North Africa and is dispersed long distances to southern Europe.

Corresponding author: J. B. Ristaino

E-mail: Jean_Ristaino@ncsu.edu

* The $e$-Xtra logo stands for "electronic extra" and indicates that supplemental material not included in the print edition is available online.

Accepted for publication 17 November 2006.

doi:10.1094/PDIS-91-6-0685

(C) 2007 The American Phytopathological Society
The Tobacco Blue Mold Warning System, located at North Carolina State University in Raleigh, provides continent-wide Internet forecasting support to tobacco growers by tracking the geographic presence and future spread of the tobacco blue mold pathogen (19). In some years, tobacco blue mold has been very severe in some areas of the United States but not in the southernmost regions, as the forecasting trajectories might have predicted $(19,28)$. Epidemics have been traced to inoculum from greenhouse transplants. Tobacco transplants that are infected by $P$. tabacina and taken to the field and planted may remain stunted, produce lower yields, or simply die $(4,15)$. Infected transplants also can introduce the pathogen to noninfested areas and these plants then can act as a reservoir for subsequent epidemics in the field (31). It is unclear whether the pathogen is capable of overwintering in infected debris, and the role of oospores in disease is not clearly understood. Populations of the pathogen are resistant to the commonly used fungicides such as metalaxyl and mefenoxam (29). Tobacco blue mold cannot be controlled by crop rotation and there is only one cultivar of Burley tobacco that is resistant to the pathogen.

A reliable and quick method of detection of the pathogen could be useful to reduce spread of the pathogen in infected plants or to identify field or aerial sources of inoculum for forecasting systems. Diagnosis can be difficult when sporulation is not observed $(4,17)$. A number of other fungal pathogens cause leaf spot and stem or systemic infections on tobacco, thus complicating diagnosis. The pathogen already may have released sporangiospores into the atmosphere by the time accurate identifications are made. Proper disease management may be problematic once a plant has become infected because most fungicides are protectants and not curative.

A polymerase chain reaction (PCR)based restriction fragment length polymorphism (RFLP) assay of nuclear and mitochondrial genes has been used to differentiate the major species of Phytophthora and strains that cause disease on different hosts $(14,20,30)$. The internal transcribed spacer (ITS) regions and the 5.8S rDNA gene have been sequenced and used in systematics at the species level for many fungal and oomycete species. However, the ITS regions have not been sequenced in $P$. tabacina. Only a single PCR-based method using random amplified polymorphic DNA (RAPDs) has been developed for detection of $P$. tabacina, and no methods have been deployed for use in the field or thoroughly tested against other tobacco pathogens $(4,38)$. Intraspecific variation has been studied with allozyme analysis and repetitive DNA probes among a limited number of isolates of P. tabacina $(23,32)$.

The objectives of this work were to sequence the ITS and 5.8S rDNA of P. tabacina and other important fungal pathogens of tobacco and to develop a specific PCR assay for the in vivo detection of the pathogen in infected tobacco leaves.

\section{MATERIALS AND METHODS}

Growth of tobacco seedlings. Tobacco seed (cvs. Burley 21 and Bergerac) were planted in small plastic trays and germinated in a mist room. The seed trays were transferred to a growth chamber at $22^{\circ} \mathrm{C}$ and were watered with Hoagland's nutrient solution (13). The seedlings were planted in small Styrofoam cups and moved to a $22^{\circ} \mathrm{C}$ greenhouse once the true leaves were formed. The tobacco plants were watered twice daily with the Hoagland's nutrient solution and exposed to long days by interrupting the regular $15-\mathrm{h}$ night period at $18^{\circ} \mathrm{C}$ with $3 \mathrm{~h}$ of extra light in the middle of the dark period. Plants at the three- to four-leaf stage were placed in sealed plastic boxes and watered with $250 \mathrm{ml}$ of Hoagland's solution 
Table 1. Isolate name, year of isolation, geographic location (county or state) of source, and name of collector of isolates of Peronospora tabacina used in this study

\begin{tabular}{|c|c|c|c|}
\hline Isolate $^{\mathbf{a}}$ & Year & Source $^{\mathbf{b}}$ & Collector ${ }^{\mathrm{c}}$ \\
\hline BPTP $^{d}$ & 1945 & Texas & Clayton \\
\hline BPTS & 1945 & Texas (subculture of BPTP) & Clayton \\
\hline 98 Kentucky & 1999 & Kentucky & P. Shoemaker \\
\hline 98 Madison & 1999 & Madison County, NC & P. Shoemaker \\
\hline 98 Virginia & 1999 & Virginia & P. Shoemaker \\
\hline 98 Watauga & 1999 & Watauga County, NC & P. Shoemaker \\
\hline Ashe (UMRS) & 1998 & Ashe County, NC & P. Shoemaker \\
\hline Brunswick Co. & 1999 & Brunswick County, NC & J. Radford \\
\hline СТ 991 & 1999 & Connecticut & J. LaMondia \\
\hline GA 991 & 1999 & Doerun, GA & P. Bertrand \\
\hline GA 992 & 1999 & Colquitt County, GA & P. Bertrand \\
\hline GA 994 & 1999 & Reno, GA & P. Bertrand \\
\hline GA 995 & 1999 & Berlin, GA & P. Bertrand \\
\hline GA 996 & 1999 & Tifton, GA & A. $C \operatorname{sinos}$ \\
\hline Greene City 1 & 1998 & Greene County, NC & A. Johnson \\
\hline Haywood Co. & 1999 & Haywood County, NC & P. Shoemaker \\
\hline JPT84 & 1984 & Jones, NC & M. Moss \\
\hline KPT 79 & 1985 & Kentucky & W. Nesmith \\
\hline KY 98 & 1999 & Kentucky & W. Nesmith \\
\hline KY Nesmith & 1999 & Kentucky & P. Shoemaker \\
\hline Lenoir Co. & 1999 & Lenior County, NC & C. E. Main \\
\hline MC Holloway & 1999 & Madison County, NC & S. Holloway \\
\hline Mexico & 1999 & Mexico & R. Rufty \\
\hline Millersville, PA & 1999 & Millersville, PA & J. Yocum \\
\hline Mitchell & 1998 & Mitchell County, NC & P. Shoemaker \\
\hline Mitchell 98 & 1998 & Mitchell County, NC & P. Shoemaker \\
\hline Moseley VA, 1A & 1999 & Moseley, VA & C. Johnson \\
\hline Moseley VA, 1B & 1999 & Moseley, VA & C. Johnson \\
\hline MRS 97 & 1999 & Haywood County, NC & P. Shoemaker \\
\hline NC-99-10 & 1999 & Buncombe County, NC & P. Shoemaker \\
\hline NC-99-3 & 1999 & Pitt County, NC & P. Shoemaker \\
\hline $\mathrm{NC}-99-4^{\mathrm{d}}$ & 1999 & Robeson County, NC & P. Shoemaker \\
\hline NC-99-6 ${ }^{\mathrm{d}}$ & 1999 & Brunswick County, NC & P. Shoemaker \\
\hline NC-99-7 & 1999 & Jones County, NC & P. Shoemaker \\
\hline NC-99-9d & 1999 & Madison County, NC & P. Shoemaker \\
\hline NPT 83 & 1984 & Northampton County, NC & P. Shoemaker \\
\hline Onslow & 1999 & Onslow County, NC & K. Benson \\
\hline OPT 79 & 1979 & Oxford & H. Spurr \\
\hline OPT 83 & 1983 & Oxford & H. Spurr \\
\hline OPT 84 & 1984 & Oxford & H. Spurr \\
\hline Columbia, $\mathrm{PA}^{\mathrm{d}}$ & 1998 & Columbia, PA & W. Nesmith \\
\hline Pennsylvania A & 1999 & Leola, PA & J. Yocum \\
\hline Pennsylvania B & 1999 & Smoketown, PA & J. Yocum \\
\hline PT 3589 A & 1989 & Buncombe County, NC & P. Shoemaker \\
\hline PT $3589 \mathrm{~F}$ & 1989 & Madison County, NC & P. Shoemaker \\
\hline PT $3589 \mathrm{~K}$ & 1989 & North Carolina & P. Shoemaker \\
\hline PT $3589 \mathrm{~L}$ & 1989 & Yancey County, NC & P. Shoemaker \\
\hline PT $3589 \mathrm{M}$ & 1989 & Yancey County, NC & P. Shoemaker \\
\hline PT $86 \mathrm{GH}$ & 1999 & Yancey County, NC & P. Shoemaker \\
\hline PT 87 W & 1999 & Weaverville County, NC & P. Shoemaker \\
\hline PT $87 Y^{d}$ & 1998 & Yancey County, NC & P. Shoemaker \\
\hline PT $88 \mathrm{~W}$ & 1999 & Haywood County, NC & P. Shoemaker \\
\hline PT 89 B & 1989 & Buncombe County, NC & P. Shoemaker \\
\hline PT91A & 1991 & Allegheny, NC & G. Atwood \\
\hline PT97H & 1997 & $\ldots$ & P. Shoemaker \\
\hline PT W 87 & 1999 & Weaverville County, NC & P. Shoemaker \\
\hline PTMRS 97 & 1999 & North Carolina & P. Shoemaker \\
\hline PTNC 96 & 1998 & Bladen County, NC & P. Shoemaker \\
\hline Stokes & 1993 & Stokes, NC & Loudermilk \\
\hline Surry Co. & 1999 & Surry County, NC & P. Shoemaker \\
\hline VA 98 & 1998 & Virginia & F. Bolick \\
\hline Virginia & 1998 & Blackstone, VA & C. Johnson \\
\hline Waynesville 1 & 1999 & Haywood County, NC & P. Shoemaker \\
\hline Waynesville 2 & 1999 & Haywood County, NC & P. Shoemaker \\
\hline Waynesville 3 & 1999 & Haywood County, NC & P. Shoemaker \\
\hline WC Bolick & 1998 & Watauga County, NC & P. Shoemaker \\
\hline
\end{tabular}

${ }^{\mathrm{a}}$ Isolate name and year of collection.

${ }^{\mathrm{b}}$ Source indicates county and state where samples were collected.

c Name of collector

${ }^{\mathrm{d}}$ DNA from these isolates were sequenced (internal transcribed spacer and 5.8S rDNA). The DNA sequences were submitted to GenBank. Accession numbers are listed in Results and Table 3. through a fiber wick placed in the bottom of the box as needed.

Collection of $P$. tabacina from field infections. Sixty-six isolates of $P$. tabacina collected from fields in North Carolina (NC), Virginia (VA), Pennsylvania (PA), Connecticut (CT), Kentucky (KY), Georgia (GA), Florida (FL), and Mexico were grown on susceptible tobacco seedlings (cvs. Burley 21 and Bergerac) to increase inoculum (Table 1). The abaxial surface of recipient leaves on healthy plants was inoculated by rubbing infected leaves containing sporangiospores from donor plants. Leaves were sprayed with chilled, sterile distilled water and returned to the sealed plastic boxes. The inoculated seedlings were grown in separate plastic boxes to prevent cross contamination among isolates of $P$. tabacina. The seedlings were grown in a growth chamber at day and night temperatures of 22 and $18^{\circ} \mathrm{C}$, respectively, and under a photoperiod of $10 \mathrm{~h}$ of light and $13 \mathrm{~h}$ of dark with $1 \mathrm{~h}$ of light interruption in the middle of the dark period. Light was provided by a combination of incandescent and fluorescent lights at an intensity of $200 \mu \mathrm{mol} / \mathrm{m}^{2} / \mathrm{s}(33)$.

Cryogenic storage of $P$. tabacina sporangiospores. Sporangiospores from lesions with sporulation were collected 5 days after inoculation. Sporangiospores were harvested by washing the newly sporulating lesions with chilled, sterile distilled water. The resulting suspension was placed in $1.5-\mathrm{ml}$ tubes and centrifuged for $2 \mathrm{~min}$ at $12,000 \mathrm{rpm}$. The supernatant was removed and the procedure repeated to reduce the volume of the suspension. The sporangiospore pellet was transferred to a cryogenic $(1.5-\mathrm{ml})$ tube. A $10 \%$ solution of sterile dimethyl sulfoxide (DMSO) was added to each $1.5-\mathrm{ml}$ centrifuge tube and the tubes were placed in a $-20^{\circ} \mathrm{C}$ freezer overnight and subsequently submersed in liquid nitrogen $\left(-195^{\circ} \mathrm{C}\right)$ for long-term storage $(3,5)$.

Isolates were stored in cryogenic storage and retrieved for subsequent use. Sporangiospores were thawed at room temperature from cryogenic storage and used for subsequent DNA extraction. The DMSO solution was removed with a sterile pipette and the sporangiospores were transferred to a sterile $1.5-\mathrm{ml}$ microcentrifuge tube, washed with sterile distilled water, and centrifuged three times at $12,000 \mathrm{rpm}$ for 2 $\min$.

Culture of other tobacco pathogens. Other important foliar and soilborne fungal pathogens of tobacco were grown on potato dextrose agar (Table 2). Mycelia from cultures in petri dishes were transferred to potato dextrose broth and grown at $25^{\circ} \mathrm{C}$ for 3 to 5 days. The potato dextrose broth was filtered and the mycelia were collected. Roughly $100 \mathrm{mg}$ of mycelia were placed in a sterile $1.5-\mathrm{ml}$ microcentrifuge tube for DNA extraction as described below and stored at $-20^{\circ} \mathrm{C}$ for future use (37). 
DNA extraction, PCR, and restriction digests. DNA was extracted from sporangiospores of $P$. tabacina and from mycelia of the other tobacco pathogens. Leaf tissue from healthy tobacco plants served as negative controls. DNA was extracted using the hexadecyltrimethylammonium bromide (CTAB) procedure $(36,37)$. The frozen sporangiospores or mycelia $(10 \mathrm{mg})$ were placed in sterile $1.5-\mathrm{ml}$ microcentrifuge tubes to which $150 \mu \mathrm{l}$ of extraction buffer (0.35 M sorbital, $0.1 \mathrm{M}$ Tris, 0.005 $\mathrm{M}$ EDTA, $\mathrm{pH} 7.5$, and $0.02 \mathrm{M}$ sodium bisulfite) was added, and tubes were vortexed. Nuclei lysis buffer $(150 \mu \mathrm{l} ; 0.2 \mathrm{M}$ Tris, 0.05 M EDTA, pH 7.5, 2.0 M NaCl, $2 \% \mathrm{CTAB}$, and $60 \mu \mathrm{l}$ of $5 \%$ sarkosyl [Nlauryl sarcosine]) was added and tubes were vortexed and incubated at $65^{\circ} \mathrm{C}$ for 15 to $30 \mathrm{~min}$. After incubation, one volume $(300 \mu \mathrm{l})$ of chloroform:isoamyl alcohol (24:1) was added to each tube and tubes were centrifuged for $15 \mathrm{~min}$ at 13,000 $\times g$ at room temperature. The aqueous phase was removed to a new tube and chloroform extraction was repeated. DNA was precipitated overnight at $-20^{\circ} \mathrm{C}$ in 0.1 volume of 3 $\mathrm{M}$ sodium acetate $(\mathrm{pH} 8.0)$ and 2 volumes of cold $100 \%$ ethanol. The supernatant was discarded; pellets were washed with $70 \%$ ethanol and dried under vacuum centrifugation. DNA was suspended in Tris-EDTA (TE; $10 \mathrm{mM}$ Tris- $\mathrm{HCl}, 0.1 \mathrm{mM}$ EDTA, $\mathrm{pH}$ 8.0). A 1:100 dilution of DNA was made of all extracted DNA for use in PCR experiments.

PCR was conducted in a 50- $\mu$ l reaction volume in thin-walled $0.2-\mathrm{ml}$ tubes by the procedure of Trout et al. (36). Briefly, $1 \mu \mathrm{l}$ of template DNA (1:100 dilution of original DNA extract in TE buffer, about $1 \mathrm{ng}$ ) was added to a $49-\mu 1$ master reaction mixture containing $5 \mu \mathrm{l}$ of $10 \times$ PCR buffer (100 mM Tris-HCl, $15 \mathrm{mM} \mathrm{MgCl}_{2}$, and $500 \mathrm{mM} \mathrm{KCl}, \mathrm{pH} 8.3$ ), $35.5 \mu \mathrm{l}$ of sterile distilled $\mathrm{H}_{2} \mathrm{O}, 1.8 \mu \mathrm{l}$ of $10 \mathrm{mM} \mathrm{MgCl} \mathrm{Mg}_{2}, 2 \mu \mathrm{l}$ of $2 \mathrm{mM}$ dNTPs, $2 \mu \mathrm{l}$ of $10 \mu \mathrm{M}$ ITS5 primer, $2 \mu \mathrm{l}$ of $10 \mu \mathrm{M}$ ITS 4 primer, and 0.2

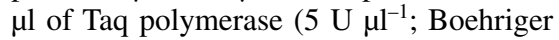
Mannheim Biochemicals, Indianapolis, IN). The universal fungal primers ITS4 and -5 were used initially to amplify DNA from $P$. tabacina and all the other tobacco pathogens (37). The primer sequences were ITS4 (5'-TCCTCCGCTTATTGA TATGC- $3^{\prime}$ ) and ITS5 (5'-GGAAGTAAA AGTCGTAACAAGG-3') (38). All reactions were overlaid with sterile mineral oil prior to thermal cycling. Thermal cycling parameters were initial denaturation at $96^{\circ} \mathrm{C}$ for $2 \mathrm{~min}$, followed by 35 cycles consisting of denaturation at $96^{\circ} \mathrm{C}$ for 1 min, annealing at $55^{\circ} \mathrm{C}$ for $1 \mathrm{~min}$, and extension at $72^{\circ} \mathrm{C}$ for $2 \mathrm{~min}$. Thermal cycling was followed by a final extension step at $72^{\circ} \mathrm{C}$ for $10 \mathrm{~min}$. Amplified products were separated on $1.6 \%$ agarose gels containing ethidium bromide at $0.5 \mu \mathrm{g} / \mathrm{ml}$ with $1 \times$ Tris-borate-EDTA (TBE) running buffer. DNA bands were visualized using a UV transilluminator. A 100-bp DNA ladder was included in each gel as a molecular size standard.

Amplified DNA from P. tabacina and the other tobacco pathogens were digested with the restriction enzymes $R s a \mathrm{I}, M s p \mathrm{I}$, HaeIII, and EcoRI to confirm the identity of each species. For each restriction digestion, $1 \mu \mathrm{l}$ of a master mix consisting of $8 \mu \mathrm{l}$ of $\mathrm{H}_{2} \mathrm{O}, 1 \mu \mathrm{l}$ of restriction enzyme, and 1 $\mu \mathrm{l}$ of the appropriate buffer (React buffer, Gibco BRL, Gaithersburg, MD) was added to $10 \mu \mathrm{l}$ of $\mathrm{PCR}$ product. The reaction mixture was incubated at $37^{\circ} \mathrm{C}$ for $3 \mathrm{~h}$ and, at the end, restriction enzymes were inactivated by heating at $65^{\circ} \mathrm{C}$ for $10 \mathrm{~min}$. The digested products were separated on $1.6 \%$ agarose gels containing ethidium bromide at $0.5 \mu \mathrm{g} / \mathrm{ml}$ with $1 \times \mathrm{TBE}$ running buffer. The RFLP patterns were visualized with a UV transilluminator.

Development of a $P$. tabacina-specific primer. Amplified PCR products (ITS4 and -5 primers) from six isolates of $P$. tabacina (Table 1) and two to three isolates of each of the 12 tobacco pathogens (Table 2) were cleaned using a QIAquick PCR Purification Kit (QIAGEN, Bothell, WA). The amplified fragments were sequenced at the University of Georgia's Molecular Genetics Instrumentation Facility on an ABI Prism 377 automated DNA sequencer (Applied Biosystems, Foster City, CA).

Table 2. Other tobacco pathogens and Peronospora species, isolate number, collector, host, and geographic location of isolates used for polymerase chain reaction and sequencing experiments

\begin{tabular}{|c|c|c|c|c|}
\hline Pathogen & $\begin{array}{l}\text { Isolate number, } \\
\text { GenBank sequence }^{\text {a }}\end{array}$ & Collector & Host & Source $^{\mathrm{b}}$ \\
\hline Alternaria alternata & $1,,^{\mathrm{c}} 2,3,{ }^{\mathrm{a}} 4$ & H. Spurr & Tobacco & $\mathrm{NC}$ \\
\hline Cercospora nicotianae & $1,2,3,{ }^{\mathrm{c}} 4$ & M. Daub & Tobacco & $\mathrm{NC}$ \\
\hline Phytophthora glovera & $\mathrm{G}-23^{\mathrm{c}}$ & D. Shew & Tobacco & Brazil \\
\hline \multirow[t]{2}{*}{ P. parasitica } & 326,371 , race $0,{ }^{c}$ race 1 & D. Shew & Tobacco & $\mathrm{NC}$ \\
\hline & 332,335 & J. Ristaino & Tobacco & $\mathrm{NC}$ \\
\hline Pythium aphanidermatum & $\mathrm{L}-22,{ }^{\mathrm{c}} \mathrm{P} 88$ & D. Shew & Tobacco & $\mathrm{NC}$ \\
\hline P. dissotocum & P013, ${ }^{\mathrm{c}}$ P012, Py 47 & W. Gutierrez & Tobacco & $\mathrm{NC}$ \\
\hline P. myriotylum & Py- $-45^{c}$ & W. Gutierrez & Tobacco & $\mathrm{NC}$ \\
\hline P. ultimum & P-74, ${ }^{\mathrm{c}}$ Py 74 & D. Shew & Tobacco & $\mathrm{NC}$ \\
\hline \multirow[t]{2}{*}{ Rhizoctonia solani } & $102^{\mathrm{c}}$ & J. Ristaino & Potato & $\mathrm{NC}$ \\
\hline & T-118 T-154, T-73 1708, 19 & D. Shew & Tobacco & $\mathrm{NC}$ \\
\hline Sclerotinia sclerotiorum & $21,28,35, \mathrm{c} 41$ & D. Shew & Tobacco & $\mathrm{NC}$ \\
\hline \multirow{3}{*}{ Sclerotium rolfsii } & SR-CC-1 ${ }^{\mathrm{c}}$ & J. Ristaino & Tobacco & $\mathrm{NC}$ \\
\hline & SR-DD-8, SR-DD-9 & J. Ristaino & Tomato & $\mathrm{NC}$ \\
\hline & SR-DD-5 & J. Ristaino & Tomato & $\mathrm{AK}$ \\
\hline Thielaviopsis basicola & $1515,{ }^{\mathrm{c}} 1523$ & D. Shew & Tobacco & $\mathrm{NC}$ \\
\hline
\end{tabular}

${ }^{a}$ Sequences from GenBank were used to confirm our sequence and restriction site data, including Alternaria alternata, AY751456, DQ323699; Cercospora nicotianae AF297230, AY266159; Phytophthora glovera, AF279126, AF79127, AF279128; Phytophthora parasitica (race 0), AY208131, DQ357827; Pythium aphanidermatum, AF271227, AB60845, AF271227, DQ298523; P. dissotocum AF271228, AF330184; P. myriotylum, DQ102701, DQ222438; P. ultimum, AY598657, AY310440; Rhizoctonia solani AY387569, AB019009; Sclerotinia sclerotiorum AB233346, DQ329537; Sclerotium rolfsii AB075305, AF499018; Thielaviopsis basicola AF275493, U97334; Peronospora farinosa AY211017; P. arenariae, AY198280; P. claytoniae, AY198281; P. polygoni, AY198282; P. holostei, AY198283; P. arthurii, AY198284; P. boni-henrici, AY198286; and P. chenopodiipolyspermi, AY198291.

${ }^{\mathrm{b}} \mathrm{NC}=$ North Carolina and $\mathrm{AK}=$ Arkansas.

${ }^{c}$ Three to five isolates of each species were sequenced. Sequences from the following isolates (and their accession numbers) were submitted to GenBank: Alternaria alternata (1), DQ059568; Cercospora nicotianae (3), DQ059569; Phytophthora glovera (G-23), DQ059570; P. parasitica (race 0), DQ059571; Pythium aphanidermatum, (L22), DQ059572; P. dissotocum (PO13) DQ059573; P. myriotylum (Py-45), DQ059574; P. ultimum (P-74), DQ059575; R. solani (102) DQ059576; Sclerotinia sclerotiorum (35), DQ059577; Sclerotium rolfsii (SR-CC-1), DQ059578; and T. basicola (1515) DQ059579.
The sequences were aligned utilizing the
computer program Clustal W (12). Addisame amplified regions of DNA from the same species were downloaded from Genspecific primer and to examine restriction DNA that was present in P. tabacina but absent in the other tobacco pathogens was ignated PTAB (5'-ATCTTTTTGCTGGCT first ITS region 106 bases downstream from the universal ribosomal primer ITS5. with the primer ITS4 in the P. tabacinaecific assay.

with DNA from 66 isolates of P. tabacina (Table 1) and other tobacco pathogens used to test the specificity of the PTAB and product was visualized utilizing $1.5 \%$ aga-

ers. Extracted DNA from P. tabacina was quantified using a spectrophotometer. $0.0125 \mathrm{ng} \mathrm{ml}^{-1}$ prior to PCR. Each dilution $(1 \mu \mathrm{l})$ was used for PCR reactions as described above with primers PTAB and 
ITS4. The experiment was conducted two times.

Detection of $P$. tabacina from fresh, air-dried, and cured tobacco leaf tissue. Tobacco leaves were inoculated and leaves containing sporulating lesions of $P$. tabacina were harvested as described previously. Leaves either were frozen, air-dried for 2 weeks, or placed in a herbarium drier at $50^{\circ} \mathrm{C}$ for 2 weeks to dry lesions and simulate tobacco curing. DNA samples were extracted from lesions containing the pathogen, from symptomless tissue adjacent to lesions, and from other uninfected leaves using the CTAB extraction protocol (36). DNA was diluted 1:100 in TE and 1 $\mu \mathrm{l}$ of template DNA was used in PCR reac- tions with the PTAB and ITS4 primers as described previously. Amplified products were visualized on $1.5 \%$ agarose gels.

\section{RESULTS}

DNA was extracted from the sporangiospores of isolates of $P$. tabacina and amplified with the ITS primer pairs ITS4 and ITS5. This region of DNA was sequenced in six isolates of P. tabacina and was 862 bp in size (Fig. 1; Table 3). Amplified DNA from all the isolates of $P$. tabacina shown in Table 1 was digested with a series of restriction enzymes. Restriction sites for RsaI and HaeIII were not found in this region of amplified DNA in any of the isolates of $P$. tabacina tested (Tables 1 and

\section{$\begin{array}{llllllllllllll}1 & 2 & 3 & 4 & 5 & 6 & 7 & 8 & 9 & 10 & 11 & 12 & 13 & 14\end{array}$}

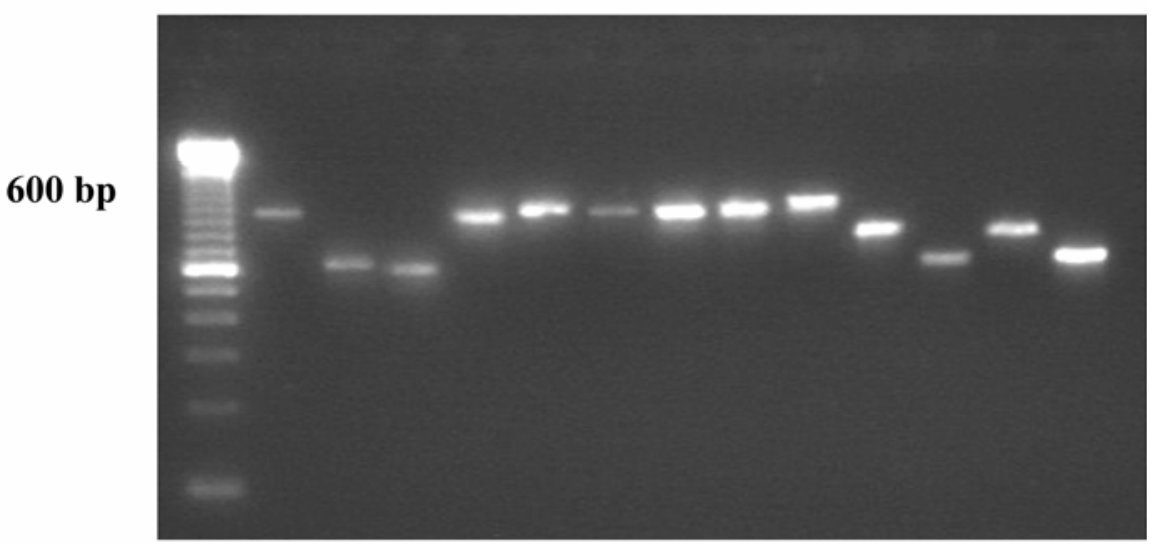

Fig. 1. Polymerase chain reaction-amplified fragments with the primers ITS4 and ITS5 from Peronospora tabacina and other tobacco pathogens. Lane 1, 100-bp ladder; lane 2, P. tabacina NC-99-9; lane 3, Alternaria alternata A4; lane 4, Cercospora nicotianae 3; lane 5, Phytophthora glovera G-23; lane 6, $P$. parasitica 335; lane 7, Pythium aphanidermatum L-22; lane 8, $P$. dissotocum Py-47; lane 9, $P$. myriotylum Py-45; lane 10, P. ultimum Py-74; lane 11, Rhizoctonia solani 1708; lane 12, Sclerotinia sclerotiorum, 21; lane 13, Sclerotium rolfsii SR-DD-5; and lane 14, Thielaviopsis basicola 1523.
3). However, restriction sites for $M s p I$ and EcoRI were found in the amplified rDNA of all the isolates of $P$. tabacina tested, and fragments of 586 and 276 bp for $M s p I$ and 540 and 322 bp for EcoRI, respectively, were observed (Table 3 ).

DNA sequences from the ITS region and the 5.8S rDNA were identical among all of the isolates of $P$. tabacina that were sequenced, and the absence of RsaI and HaeIII and the presence of the MspI and EcoRI restriction sites were confirmed (Table 3). The sequence data was submitted to GenBank ( $P$. tabacina NC-99-9, DQ059580; BPTP DQ67896; PT 87 Y, DQ067897; NC-99-4, DQ067898; NC-996, DQ067899; and Columbia, DQ067900).

The ITS regions and 5.8S rDNA from the other tobacco pathogens also were digested with restriction enzymes RsaI, MspI, HaeIII, and EcoRI (Table 3). Sequence data was used to design the PTAB primer (Table 2). Sequence data from other closely related Peronospora spp. were obtained from GenBank (2).

Specificity of the PTAB-specific primer. The PTAB and ITS4 primers were used to amplify rDNA from 66 isolates of $P$. tabacina and isolates of other species that infect tobacco pathogens (Tables 1 and 2). The PTAB primer amplified a 764-bp DNA fragment from P. tabacina (Fig. 2). DNA from all the species was amplified with primers ITS4 and -5 prior to PCR, with the primers PTAB and ITS4 as a positive control, and an amplified fragment was obtained for each of the other species (Fig. 1). The PTAB/ITS4 primer pair amplified DNA only from $P$. tabacina and not the other tobacco pathogens shown in Table 2. The PTAB primer annealing site also was present in several other closely related Peronospora spp. that are in the same

Table 3. Tobacco pathogens, size of internal transcribed spacer (ITS) and 5.8S rDNA region, and restriction fragment sizes with restriction enzymes RsaI, MspI, HaeIII, or EcoRI

\begin{tabular}{|c|c|c|c|c|c|}
\hline \multirow[b]{2}{*}{ Pathogen } & \multicolumn{5}{|c|}{ Fragment size $(\mathbf{b p})^{\mathbf{a}}$} \\
\hline & rDNA and ITS amplicon & RsaI & MspI & HaeIII & EcoRI \\
\hline Peronospora tabacina ${ }^{\mathrm{b}}$ & 862 & ns & 586,276 & ns & 540,322 \\
\hline Alternaria alternata ${ }^{\mathrm{c}}$ & 552 & $251,215,86$ & 412,146 & 415,137 & 297,255 \\
\hline Cercospora nicotianae & 535 & ns & $269,123,143$ & $339,88,77,41$ & 282,253 \\
\hline Phytophthora glovera & 817 & $342,274,106,85,10$ & $270,221,209,117$ & 530,287 & $\mathrm{~ns}$ \\
\hline P. parasitica & 866 & 521,345 & $378,340,120,28$ & $667,169,30$ & ns \\
\hline Pythium aphanidermatum & 881 & $372,205,194,110$ & ns & 622,259 & 559,322 \\
\hline P. dissocticum & 833 & $227,188,173,135,110$ & $\mathrm{~ns}$ & 610,223 & 551,282 \\
\hline P. myriotylum & 834 & $361,190,173,110$ & ns & 610,224 & 553,281 \\
\hline P. ultimum & 857 & $384,227,136,110$ & ns & ns & 553,281 \\
\hline Rhizoctonia solani & 690 & 507,183 & ns & $525,101,64$ & 339,351 \\
\hline Sclerotinia sclerotiorum & 532 & 368,164 & 319,213 & 412,120 & 266,266 \\
\hline Sclerotium rolfsii & 694 & 570,124 & 545,149 & ns & ns \\
\hline Thielaviopsis basicola & 554 & 476,63 & 448,106 & 385,169 & 298,256 \\
\hline
\end{tabular}

${ }^{a}$ Restriction fragment sizes determined from sequence data and GenBank accessions numbers shown in Table 2; ns signifies that the restriction site was not found in the amplified DNA.

${ }^{\mathrm{b}}$ The following isolates of Peronospora tabacina were sequenced (ITS and 5.8S rDNA) and the DNA sequences were submitted to GenBank. Accession numbers are: P. tabacina isolates NC-99-9, DQ059580; BPTP DQ67896; PT 87 Y, DQ067897; NC-99-4, DQ067898; NC-99-6, DQ067899; and ColumbiaPA, DQ067900.

${ }^{\mathrm{c}}$ Sequences from the following isolates were submitted to GenBank. Accession numbers are: Alternaria alternata (1), DQ059568; Cercospora nicotianae (3), DQ059569; Phytophthora glovera (G-23), DQ059570; P. parasitica (race 0), DQ059571; Pythium aphanidermatum, (L22), DQ059572; P. dissotocum (PO13) DQ059573; P. myriotylum (Py-45), DQ059574; P. ultimum (P-74), DQ059575; Rhizoctonia solani (102) DQ059576; Sclerotinia sclerotiorum (35), DQ059577; Sclerotium rolfsii (SR-CC-1), DQ059578; and Thielaviopsis basicola (1515) DQ059579. 
clade (GenBank accession numbers AY198280 to AY198284, AY198286, AY198291, and AY211017); however, these species do not infect tobacco and have different restriction sites for the suite of enzymes examined in our study and can be separated readily from $P$. tabacina (2; data not shown).

Sensitivity of PTAB and ITS4 primers. Detection of $P$. tabacina was positive by gel electrophoresis down to levels of DNA of $0.0125 \mathrm{ng} \mathrm{ml}^{-1}$ in repeated experiments (data not shown).

PCR of $P$. tabacina from fresh, airdried, and cured leaf tissue of tobacco. The pathogen was detected consistently using PTAB and ITS4 in fresh lesions from infected leaf material (Fig. 3). The percentage of samples that were positive by PCR detection in known infected leaves was $100 \%$ in repeated testing of batches of 10 leaves each. The PTAB/ITS4 primer pair also was used to amplify DNA from infected air-dried and heat-cured tobacco leaves and noninfected healthy control leaves. Host DNA was not amplified by the primers. Pathogen DNA was detected in both air-dried and cured leaf material (Fig.
4). The pathogen also was detected in fresh tissue in symptomless areas adjacent to leaf lesions (Fig. 4).

\section{DISCUSSION}

The ability to rapidly and accurately identify pathogens causing plant disease is extremely important in management. We designed a specific primer called PTAB that is located in the spacer one region of the ribosomal DNA for use in the detection of $P$. tabacina in infected tobacco tissue. DNA from $P$. tabacina was successfully amplified from all isolates tested with PTAB and ITS4. The PTAB and ITS4 primers did not amplify DNA from the other common fungal species that infect tobacco or from the tobacco host. Therefore, the primers are specific for $P$. tabacina.

$P$. tabacina can be differentiated from several different foliar and soilborne tobacco pathogens, including: Alternaria alternata, Cercospora nicotianae, Phytophthora glovera, P. parasitica, Pythium aphanidermatum, $P$. dissotocum, $P$. myriotylum, $P$. ultimum, Rhizoctonia solani, Sclerotinia sclerotiorum, Sclerotium rolfsii, and Thielaviopsis basicola, by PCR-RFLP methods. The enzyme RsaI was the most useful for digestion of DNA amplified from sporangiospores or pure cultures because restriction fragment patterns were unique for most of the pathogens examined, except $P$. aphanidermatum and $P$. myriotylum. The PCR-RFLP assays are useful for identification of isolates that have been obtained in culture. However, because Peronospora tabacina is an obligate pathogen, this method is of limited use for diagnosis in infected plant material.

The use of PCR has several advantages over previous diagnostic techniques $(16,38)$. The PTAB and ITS4 primers specifically amplify $P$. tabacina DNA, and this region of DNA is distinct from the other common tobacco pathogens tested. Wiglesworth designed a primer pair (1602A/B) that also specifically amplified P. tabacina DNA (38). However, their primer was developed based on RAPD markers and it is unknown what region of the genome of $P$. tabacina is actually amplified with these primers; therefore, they may be subject to genetic variation within populations (32). Also, their primers have

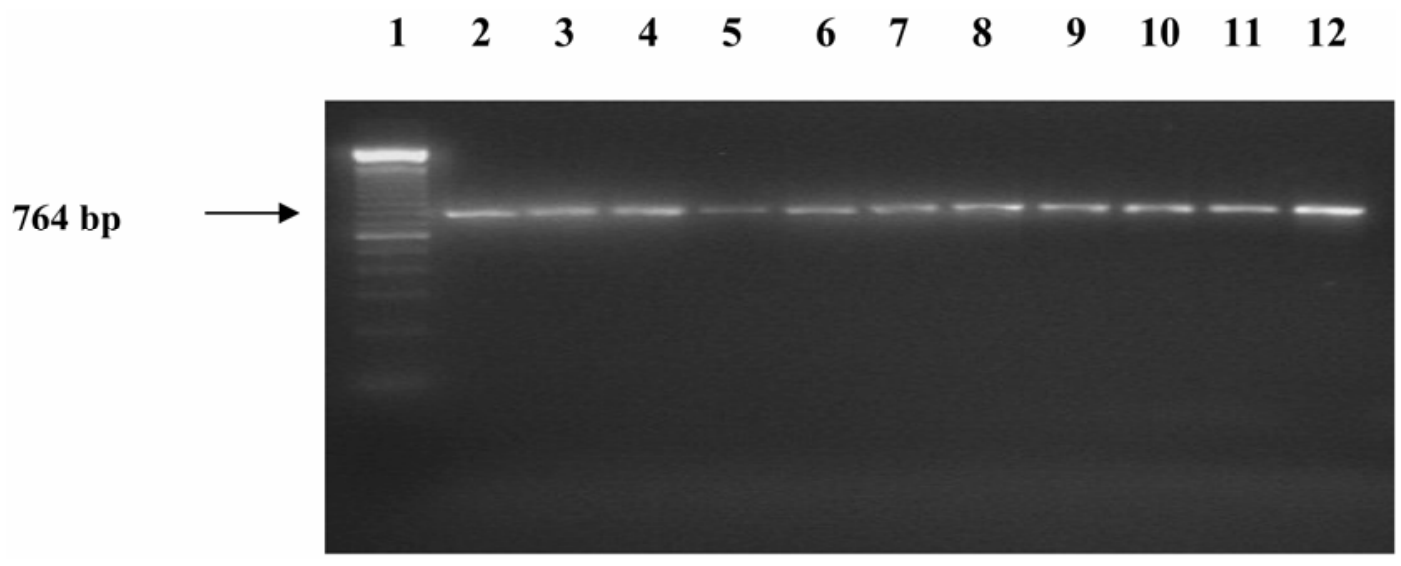

Fig. 2. Polymerase chain reaction amplified DNA with primers PTAB and ITS4 from sporangiospores from 11 different isolates of Peronospora tabacina, including lane 1, 100-bp ladder; lane 2, OPT83; lane 3, OPT84; lane 4, PT97H; lane 5, KPT; lane 6, BPTP; lane 7, BPTS; lane 8, JPT84; lane 9, OPT85; lane10, JPT; lane 11, Stokes; lane 12, PT91A.

$\begin{array}{lllllllllllll}1 & 2 & 3 & 4 & 5 & 6 & 7 & 8 & 9 & 10 & 11 & 12 & 13\end{array}$

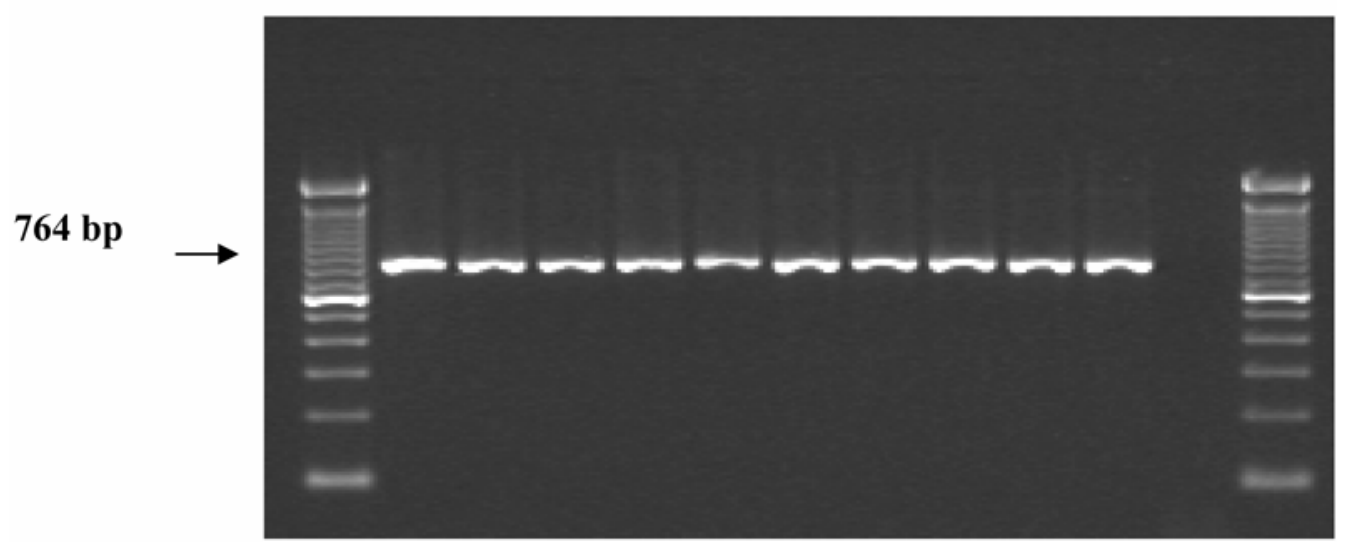

Fig. 3. Detection of Peronospora tabacina with primers PTAB and internal transcribed spacer 4 from 10 infected fresh tobacco lesions (lanes 2-11). Nontemplate control is in lane 12 and lanes 1 and 13 are 100-bp ladders. 


\section{$\mathrm{H}$ Air-dried Cured leaf Fresh leaf \\ - SL NSL NSP SL NSL NSP SL NSL NSP nt}

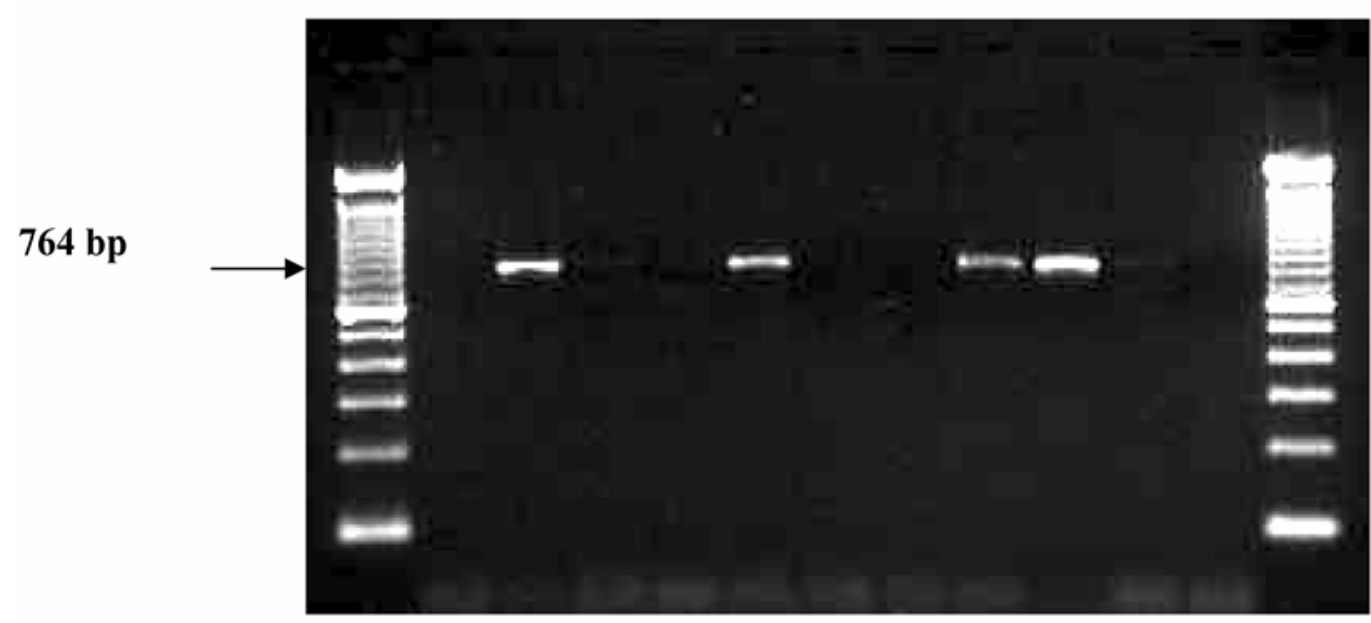

\section{$\begin{array}{lllllllllllll}1 & 2 & 3 & 4 & 5 & 6 & 7 & 8 & 9 & 10 & 11 & 12 & 13\end{array}$}

Fig. 4. Amplified DNA from Peronospora tabacina-infected tobacco leaves. Polymerase chain reaction products shown are from healthy (H) (lane 2), airdried (lanes 3-5), flue-cured (6-8), and fresh lesions (9-11) and nontemplate (nt) controls (lane 12). Lanes 1 and 13, 100-bp ladder. Samples were from the symptomatic lesions (SL) (lanes 3, 6, and 9), nonsymptomatic areas adjacent to the lesion (NSL) on the same leaf (lanes 4, 7, and 10) or from a nonsymptomatic leaf (NSP) on the same plant (lanes 5, 8, and 11).

not been tested widely against multiple isolates of $P$. tabacina or other tobacco pathogens (4). The rDNA region we amplified is extremely conserved and has been used for species identification previously in other Oomyceteous and fungal plant pathogens $(10,25-27,30)$. Our primers are more likely to remain useful for specieslevel diagnostics among many isolates because they worked well with collections of 66 isolates from 1945 to the present.

Other options for pathogen genotyping include RAPDs and RFLP fingerprinting $(4,38)$. RAPDs are useful because they may be able to differentiate different strains of a particular species; however, RAPDs are very sensitive to "nontarget" DNA and may give false positives (39). Sukno developed DNA probes for genotyping $P$. tabacina using RFLP fingerprinting, but the assays were subject to inconsistency due to contaminating bacterial DNA (32). Because our primers are specific for eukaryotic DNA, bacterial contamination was not an issue. The RFLP methods are very time consuming and require large quantities of pure DNA $(4,10)$. Dot blots and reverse dot blots might be useful for pathogen diagnostics (16). Several different pathogens could be tested in a single assay; however, the testing procedure is more complicated than a quick PCR test.

Diagnosis of $P$. tabacina in infected tobacco can be a difficult task. Visual observation of symptomatic sporulating lesions followed by microscopic examination is considered the minimum requirement for positive identification of tobacco blue mold $(17,38)$. In addition, plants with systemic blue mold do not exhibit classical symptoms. The ability to quickly detect the tobacco blue mold pathogen where early signs of infection such as deformed leaves or chlorosis first appear but before sporulation occurs will greatly enhance the ability to identify the disease in transplants. This ability to accurately detect and confirm $P$. tabacina with confidence will aid extension personnel and growers with tough management decisions. This PCR method will allow a quick determination of whether plants are infected with the pathogen and allow diagnosticians to determine the extent of the problem in the field, seed bed, or greenhouse. The decision to spray or not to spray, or even to destroy the crop, can be very costly and these decisions are not made lightly. The PTAB and ITS4 primers could greatly aide the riskassessment process (39). The PTAB and ITS4 primers were tested and work well in pathogen-infected fresh, air-dried, and cured tobacco tissue and do not amplify host DNA. The primer is very robust in infected host material and consistently yielded positive results in leaves with symptoms.

Tobacco blue mold is a disease of tobacco that has the capability of causing an explosive epidemic under the proper environmental conditions. Because the disease is very common and damaging to tobacco in the southeastern United States, along the eastern seaboard of the United States into Canada, and in Europe, the use of specific primers for the positive diagnosis of $P$. tabacina in infected tobacco could alleviate the necessity of waiting for the visual observation of sporulating lesions. We currently are developing a real-time PCR assay for the pathogen, as has been done with related oomycetes including Phytophthora ramorum and other Peronospora spp. $(2,11)$. Ideally, an assay that can be deployed to analyze samples in the field should be developed to enable rapid and accurate detection of $P$. tabacina by extension and regulatory personnel.

\section{ACKNOWLEDGMENTS}

We thank C. Main, P. Shoemaker, and M. Daub for their advice on the advisory committee of A. Johnson; and many collaborators listed in Tables 1 and 2 who provided disease notification information to the Tobacco Blue Mold Warning System at North Carolina State University and supplied infected plant material or isolates of $P$. tabacina. The North Carolina Tobacco Foundation, the North Carolina Tobacco Commission, and the Phillip Morris Company provided funding for supplies, the assistantship for A. Johnson, and several undergraduate student interns.

\section{LITERATURE CITED}

1. Aylor, D. E., and Taylor, G. S. 1982. Longrange transport of tobacco blue mold spores. Agric. Meteorol. 27:217-232.

2. Belbahri, L., Calmin, G., Pawlowski, J., and Lefort, F. 2005. Phylogenetic analysis and real time PCR detection of a presumably undescribed Peronospora species on sweet basil and sage. Mycol. Res. 109:1276-1287.

3. Bromfield, K.R., and Schmitt, C. G. 1967. Cryogenic storage of conidia of Peronospora tabacina. Phytopathology 57:1133.

4. Caiazzo, R., Tarantino, P., Porrone, F., and Lahoz, E. 2006. Detection and earl diagnosis of Peronospora tabacina Adam in Tobacco Plants with systemic infection. J. Phytopathol. 154:432-435.

5. Cohen, Y., and Kuc, J. 1980. Infectivity of conidia of Peronospora tabacina after freezing and thawing. Plant Dis. 64:549-550.

6. Cohen, Y., Pe'er, S., Balass, O., and Coffey, M 1987. A fluorescent technique for studying growth of Peronospora tabacina on leaf surfaces. Phytopathology 77:201-204.

7. Cruickshank, I. A. M. 1989. Effect of environment on sporulation, dispersal, longevity, and germination of conidia of Peronospora hyoscyami, Pages 217-252 in: Blue Mold of Tobacco. W. E. McKeen, ed. American Phyto- 
pathological Society Press, St. Paul, MN

8. Davis, J. M., Main, C. E., and Nesmith, W. C. 1990. Aerobiological aspects of the Kentucky blue mold epidemic of 1958, Pages 55-71 in: Blue Mold of Tobacco. W. E. McKeen, ed. American Phytopathological Society Press, St. Paul, MN.

9. Davis, J. M., and Monahan, J. F. 1991. Climatology of air parcel trajectories related to the atmospheric transport of Peronospora tabacina. Plant Dis. 75:706-711.

10. Edel, V., Steinberg, C., Avelange, I., Laguerre, G., and Alabouvette, C. 1995. Comparison of three methods for the characterization of Fusarium oxysporum strains. Phytopathology 85:579-585.

11. Hayden, K. J., Rizzo, D., Tse, J., and Garbelotto, M. 2004. Detection and Quantification of Phytophthora ramorum from California Forests using a real-time polymerase chain reaction assay. Phytopathology 94:1075-1083.

12. Higgins, D. G., and Sharp, P. M. 1989. Fast and sensitive multiple sequence alignments on a microcomputer. CABIOS 5:151-153.

13. Hoagland, D. R. 1920. Optimum nutrient solutions for plants. Science 52:562.

14. Kroon, L. P. N. M., Verstappen, E. C. P., Kox, L. F. F., Flier, W. G., and Bonants, P. J. M. 2004. A rapid diagnostic test to distinquish American and European Populations of Phytophthora ramorum. Phytopathology 94:613-620.

15. Kucharek, T. A., Young, T. R., and Thomas, W. D. 1996. Occurrences of and some factors affecting blue mold of tobacco in Florida from 1921 to 1995. Proc. Soil Crop Sci. Soc. Fla. 55:81-85.

16. Levesque, C. A., Harlton, C. E., and de Cock, A. W. A. M. 1998. Identification of some Oomycetes by reverse dot blot hybridization. Phytopathology 88:213-222.

17. Lucas, G. B. 1975. Diseases of Tobacco. Biological Consulting Associates, Raleigh, NC.

18. Main, C. E. 1995. Tobacco blue mold epidemic of 1995 in the United States. Coresta Meeting Report, Oxford

19. Main, C. E., Keever, T., Holmes, G., and
Davis, J. 2001. Forecasting long-range transport of downy mildew spores and plant disease epidemics. APS Net Feature, April-May 2001. Online publication.

20. Martin, F. N., and Tooley, P. W. 2004. Identification of Phytophthora isolates to species level using restriction fragment length polymorphism analysis of a polymerase chain reaction amplified region of mitochondrial DNA. Phytopathology 94:983-991.

21. McGrath, H., and Miller, P. R. 1958. Blue mold of tobacco. Plant Dis. Rep. S. 250:1-35.

22. Menetrez M. L., and Spurr, H. W., Jr. 1990. Attachment of Peronospora tabacina Adam sporangia to surfaces. Tob. Sci. 34:88-92.

23. Micales, J. A., Bonde, M. R., and Peterson, G. L. 1988. Isozyme analysis and aminopeptidase activities within the genus Peronosclerospora. Phytopathology 78:1396-1402.

24. Moss, M. A., and Main, C. E. 1988. The effect of temperature on sporulation and viability of isolates of Peronospora tabacina collected in the United States. Phytopathology 78:110-114.

25. Moukhamedov, R., Hu, X., Nazar, R. N., and Robb, J. 1994. Use of polymerase chain reaction-amplified ribosomal intergenic sequences for the diagnosis of Verticillium tricorpus. Phytopathology 84:256-259.

26. Nazar, R. N. 1982. The eukaryotic 5.8 and $5 \mathrm{~S}$ ribosomal RNAs and related rDNAs. Cell Nucleus 11:1-28.

27. Nazar, R. N., Hu. X., Schmidt. J., Culham, D., and Robb, J. 1991. Potential use of PCRamplified ribosomal intergenic sequences in the detection and differentiation of Verticillium wilt pathogens. Physiol. Mol. Plant Pathol. 39:1-11.

28. Nesmith, W. C. 1984. The North American blue mold warning system. Plant Dis. 68:933936.

29. Reuveni, M., Nesmith, W., and Siegel, M. R. 1985. A bioassay using detached tobacco leaves to detect the sensitivity of Peronospora tabacina to fungicides. Pestic. Sci. 16:244.

30. Ristaino, J. B., Madritch, M., Trout, C. L., and Parra, G. 1998. PCR amplification of ribo- somal DNA for species identification in the plant pathogen genus Phytophthora. Appl. Environ. Microbiol. 68:948-954.

31. Shoemaker, P. B. 2001. Disease management. Pages 7-90 in: 2001 Burley Tobacco Information Notes. North Carolina Cooperative Extension Service, Raleigh.

32. Sukno, S., Taylor, A., and Farman, M. 2002. Genetic uniformity among isolates of Perono spora tabacina, the tobacco blue mold pathogen. Phytopathology 92:1236-1244.

33. Thomas, J. F., and Downs, R. J. 1991. Phytotron Procedural Manual for ControlledEnvironmental Research at the Southeastern Plant Environment Laboratory. North Carolina State University Technical Bulletin.

34. Todd, F. A. 1981. The blue mold story. Pages 9-25 in: Blue mold Symposium II. F. A. Todd, ed. 29th Tobacco Workers Conference, Lexington, KY.

35. Trigiano, R. N., Van Dyke, C. G., Spurr, H.W. Jr., and Main, C. E. 1985. Ultrastructure of sporangiophore and sporangium ontogeny of Peronospora tabacina. Tob. Sci. 29:116-121.

36. Trout, C. L., Ristaino, J. B., Madritch, M., and Wangsomboondee, T. 1997. Rapid detection of Phytophthora infestans in late blight infected tissue of potato and tomato using PCR. Plant Dis. 81:1042-1048.

37. White, T. J., Bruns, T., Lee S., and Taylor, J. 1990. Amplification and direct sequencing of fungal ribosomal RNA genes for phylogenetics. Pages 315-322 in: PCR Protocols: A Guide to Methods and Applications. M. A. Innis, D. H. Gelfand, J. J. Sninshy, and T. J. White, eds. Academic Press, New York.

38. Wiglesworth, M. D., Nesmith, W. C., Schardl, C. L., Li, D., and Siegel, M. R. 1994. Use of specific repetitive sequences in Peronospora tabacina for the early detection of the tobacco blue mold pathogen. Phytopathology 84:425 430.

39. Zhang, Z., Li, Y. Z., Qi, L. J., and Zhang, L. 1994. Viability test for Peronospora tabacina in stored Greek oriental tobacco. Bull. OEPP 24:113-119. 